\title{
Pengembangan Perangkat Pembelajaran Berbasis Model Problem Based Learning Untuk Meningkatkan Hasil Belajar Siswa Pada Pembelajaran Sosiologi Kelas XI IPS di SMAN 1 Payakumbuh
}

\author{
Nafsun Zakia ${ }^{1}$, Ike Sylvia ${ }^{2}$ \\ 1,2Universitas Negeri Padang; Padang, Indonesia \\ Email: nafsunzakia02@gmail.com, $\underline{\text { ikesylvia@fis.unp.ac.id }}$
}

\begin{abstract}
Abstrak
Penelitian ini bertujuan untuk mengetahui apakah perangkat pembelajaran yang dikembangkan dapat bernilai valid, praktis, dan efektif untuk dipakai didalam pembelajaran Sosiologi kelas XI IPS di SMAN 1 Payakumbuh. Selain itu, penelitian ini juga bertujuan untuk meningkatkan keaktifan dan pemahaman peserta didik dalam pembelajaran Sosiologi, sehingga diharapkan akan dapat meningkatkan hasil belajar Sosiologi peserta didik. Subjek dari penelitian ini adalah siswa kelas XI IPS 1 di SMAN 1 Payakumbuh. Data yang diperoleh berasal dari tiga instrumen penelitian yaitu instrumen validitas yang akan diperoleh dari validator dosen dan guru Sosiolog, instrumen praktikalitas yang akan diperoleh dari peserta didik sebagai subjek penelitian, dan instrumen efektif yang akan diperoleh dari hasil pretest dan posttest peserta didik. Data validitas dan praktikalitas dioleh dengan cara menghitung rata-rata skor kemudian hasilnya dikonversikan ke dalam skala lima. Data efektifitas berupa hasil pretest dan posttest diolah menggunakan rumus T-test dengan perbandingan $\mathrm{T}$ hitung dan $\mathrm{T}$ Tabel. Hasil dari data efektifitas menunjukkan bahwa pembelajaran dengan menggunakan perangkat pembelajaran berbasis model problem based learning memiliki hasil yang efektif dilihat dari perbedaan yang signifikan antara pretest dan posttest.

Kata kunci: Perangkat Pembelajaran, Problem Based Learning, Hasil Belajar
\end{abstract}

Abstract
This study aims determine whether the learning tools developed can be valid, practical, and effective value for use in learning Sociology class XI IPS at SMAN 1 Payakumbuh. In addition, this study also aims to increase the activeness and understanding of students in learning Sociology, so that it is expected to be able to improve the learning outcomes of students' Sociology. The subjects of this study were students of class XI IPS 1 at SMAN 1 Payakumbuh. The data obtained came from three research instruments, namely the validity instrument that will be obtained from the lecturer and teacher validator lecturers, practicality instruments that will be obtained from students as research subjects, and effective instruments that will be obtained from the students' pretest and posttest results. Data validity and practicality obtained by calculating the average score then the results are converted to a scale of five. Effectiveness data in the form of pretest and posttest results were processed using the $T$-test formula with a comparison of $T$ arithmetic and $T$ table. The results of the effectiveness data show that learning by using learning tools based on problem based learning models has effective results seen from the significant differences between pretest and posttest.

Keywords: Learning Tools, Problem Based Learning, Learning Outcomes

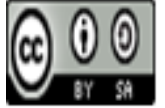

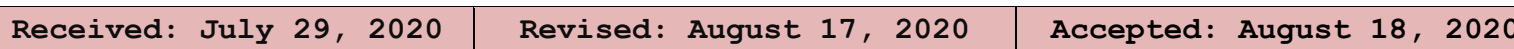




\section{Pendahuluan}

Pendidikan merupakan salah satu hal yang penting dalam upaya membangun bangsa yang cerdas dan berkarakter. Melalui pendidikan, para penerus bangsa akan dididik untuk menjadi generasi penerus bangsa yang mempunyai sumber daya manusia yang tinggi dan mampu bersaing dengan bangsa asing. Menurut Undang-Undang No.20 tahun 2003 Bab 1 Pasal 1 (ayat 1) menjelaskan bahwa pendidikan merupakan suatu usaha untuk menciptakan suasana belajar dan proses pembelajaran dengan tujuan agar siswa dapat mengembangkan potensi yang dimilikinya baik itu kekuatan spiritual keagaamaan, pengendalian diri, akhlak yang mulia, keterampilan yang dibutuhkan oleh dirinya, maupun kecerdasan yang berguna bagi dirinya, masyarakat, bangsa dan negara yang dilakukan secara sadar dan terencana. Untuk mewujudkan tujuan pendidikan tersebut, perlu adanya usaha dari semua pihak salah satunya dengan penerapan kurikulum 2013 dan juga penentuan prinsip pembelajaran yang tepat agar tujuan dari pendidikan dapat tercapai(Undang-Undang No. 20 Tahun 2003 Bab 1 Pasal 1 Ayat 1 tentang Sistem Pendidikan Nasional).

Kurikulum yang digunakan pada saat ini adalah kurikulum 2013, dimana peserta didik dituntut untuk memiliki pengalaman belajar dengan memberikan penekanan perlunya peserta didik melakukan penyelidikan ilmiah. Dengan penyelidikan ilmiah ini diharapkan peserta didik mampu mensinkronisasi antara pengetahuan yang didapatkannya dikelas dengan kenyataan yang ditemuinya sehari-hari (Sylvia, Anwar, \& Khairani, 2019). Model pembelajaran aktif (student active learning) dan prinsip pembelajaran yang berpusat pada siswa (student center learning) merupakan ciri pembelajaran saat ini yang mutlak harus diaplikasian dengan sungguh-sungguh dalam mencapai ketuntasan kompetensi yang ditetapkan sekaligus memperkuat implementasi kurikulum 2013 (Mukminan, 2013). Namun dari hasil wawancara yang dilakukan, didapatkan hasil bahwa pembelajaran Sosiologi yang berlangsung di SMAN 1 Payakumbuh cenderung menggunakan metode ceramah dan tanya jawab, hanya sesekali menggunakan metode diskusi dan proses pembelajaran kurikulum 2013. Proses pembelajaran cenderung berpusat pada guru (teacher center learning) sehingga peserta didik cenderung menjadi pasif dalam pembelajaran. Selain itu pembelajaran hanya terpaku pada LKS yang diperjual belikan di kelas, sehingga peserta didik kurang tertarik dengan pembelajaran Sosiologi. Dampak dari hal tersebut adalah hasil belajar peserta didik pada pembelajaran Sosiologi cenderung rendah dan tidak mencapai niai KKM (Kriteria Ketuntasan Minimal).

Salah satu model pembelajaran aktif yang dianjurkan dalam kurikulum 2013 adalah problem based learning (Mukminan, 2013). Menurut Arends pembelajaran berdasarkan masalah (problem based learning) merupakan suatu pendekatan pembelajaran dimana siswa mengerjakan permasalahan yang autentik dengan maksud untuk menyusun pengetahuan mereka sendiri, mengembangkan inkuiri dan keterampilan berpikir tingkat lebih tinggi, mengembangkan kemandirian dan percaya diri (Al-Thabany \& Badar, 2015). Pembelajaran Sosiologi kelas XI mengharapkan peserta didik memiliki kepekaan dalam menghadapi masalah sosial serta dapat bertanggung jawab terhadap pemecahan masalah(Sylvia et al., 2019). Model pembelajaran problem based learning memiliki keunggulan yaitu dapat merangsang kemajuan berpikir peserta didik untuk menyelesaikan suatu permasalahan yang dihadapi dengan tepat dan juga dapat membuat pendidikan lebih relevan dengan kehidupan (Sumantri, 2016). Selain itu model pembelajaran problem based learning menuntut peserta didik untuk mampu menganalisa permasalahan berupa fakta dan fenomena yang ada di masyarakat, sehingga dengan begitu peserta didik dapat mengasah kemampuannya dalam memecahkan masalah(Argusni \& Sylvia, 2018). Hal ini sesuai dengan penelitian yang dilakukan oleh Aida Fariroh dan Yustinus Ulung Anggraito dimana hasil penelitian menunjukkan bahwa pengembangan perangkat pembelajaran berbasis problem based learning dapat meningkatkan hasil belajar siswa, kemampuan berpikir kritis siswa, dan sikap ilmiah siswa dalam pembelajaran (Fariroh \& Anggraito, 2015). Oleh karena itu 
peneliti berasumsi bahwa model pembelajaran problem based learning dapat menjadi salah satu solusi dalam mengatasi permasalahan yang terjadi pada pembelajaran Sosiologi di SMAN 1 Payakumbuh.

\section{Metode Penelitian}

Metode penelitian yang digunakan pada penelitian ini adalah Research and Development atau $\mathrm{RnD}$. Penelitian dan pengembangan adalah suatu proses atau langkah-langkah untuk mengembangkan suatu produk baru atau menyempurnakan produk yang telah ada, yang dapat dipertanggung jawabkan (Sugiyono, 2009).

Model pengembangan yang digunakan adalah model ADDIE, yang terdiri dari 5 tahap yaitu : 1) Tahap Analisis (Analysis), 2) Tahap Desain (Design), 3) Tahap Pengembangan (Development), 4) Tahap Implementasi (Implementation), dan 5) Tahap Evaluasi (Evaluation) (Jasmin, 2018).

Dalam penelitian ini terdapat tiga angket yang dibuat, yaitu angket validitas RPP yang diisi oleh dosen dan guru untuk mengetahui kelayakan RPP (Rencana Pelaksanaan Pembelajaran) yang akan diuji cobakan, angket validitas LKPD yang diisi oleh dosen dan guru untuk mengetahui kelayakan LKPD (Lembar Kerja Peserta Didik) yang akan diuji cobakan, angket praktikalitas produk yang diisi oleh peserta didik sebanyak 30 orang sebagai subjek penelitian untuk mengetahui apakah produk yang telah diuji cobakan praktis atau tidak.

Teknik analisis data yanng digunakan untuk mengolah data dengan rumus validitas yaitu dengan mencari rata-rata skor yang diperoleh dari angket, yaitu sebagai berikut:

$$
\begin{aligned}
& x=\frac{\Sigma x}{n} \\
X= & \text { rata-rata } \\
\Sigma x & =\text { jumlah skor } \\
N= & \text { jumlah responden }
\end{aligned}
$$

Adapun tabel skala lima yang digunakan untuk mengkonversi hasil rata-rata yang telah dicari untuk mendapatkan kesimpulan adalah sebagai berikut:

\section{Tabel 1. (Tabel Skala Lima)}

\begin{tabular}{ccc} 
No & Interval & Kriteria \\
\hline 5 & $4,2-5$ & Sangat Baik \\
\hline 4 & $3,4-4,2$ & Baik \\
\hline 3 & $2,6-3,4$ & Cukup Baik \\
\hline 2 & $1,8-2,6$ & Kurang Baik \\
\hline 1 & $0-1,8$ & Tidak Baik \\
\hline
\end{tabular}

Selain itu, untuk mengolah data angket praktikalitas produk menggunakan rumus sebagai berikut:

$$
\begin{aligned}
& x=\frac{\Sigma x}{n} \\
& X=\text { rata-rata skor } \\
& \Sigma x=\text { jumlah skor } \\
& N=\text { jumlah responden }
\end{aligned}
$$

Adapun untuk melihat kepraktisan produk dapat menggunakan skala lima sebagai berikut:

$5=$ sangat praktis

$4=$ praktis

$3=$ cukup praktis

$2=$ kurang praktis

$1=$ tidak praktis 


\section{Hasil dan Pembahasan}

\section{Hasil}

\section{Tahap analisis (analysis)}

Tahap analisis ini terdiri dari 3 analisis, yaitu:

\section{Analisis kebutuhan}

Berdasarkan hasil observasi pada analisis kebutuhan, didapatkan data bahwa RPP yang dibuat sudah mengacu pada kurikulum 2013 dengan KI dan KD yang juga telah disesuaikan dengan kurikulum 2013. Media yang digunakan dalam pembelajaran lebih banyak berupa gambar, sumber belajar yang digunakan dalam pembelajaran berupa buku yang disediakan oleh perpustakaan. Sementara itu metode pembelajaran yang diterapkan berupa ceramah dan tanya jawab, hanya sesekali menggunakan metode diskusi.

\section{Analisis kurikulum}

Berdasarkan hasil analisis kebutuhan diatas, diperoleh data bahwa kurikulum yang digunakan di SMAN 1 Payakumbuh merupakan kurikulum 2013, instrumen penelitian yang dibuat oleh peneliti disesuaikan dengan kurikulum 2013.

\section{Analisis karakter peserta didik}

Berdasarkan observasi dan wawancara yang telah dilakukan, diperoleh data bahwa terdapat beberapa karakteristik peserta didik dalam pembelajaran Sosiologi, yaitu sebagai berikut: (1) Peserta didik kurang berpartisipasi aktif dalam pembelajaran Sosiologi. Hal ini disebabkan karena pendekatan pembelajaran yang digunakan yaitu teacher center learning, sehingga peserta didik hanya menerima apa yang diberikan oleh guru. (2) Peserta didik kurang tertarik dengan pembelajaran Sosiologi. Karakteristik ini terlihat dari aktivitas peserta didik yang lebih banyak melakukan aktivitas diluar pembelajaran Sosiologi saat pembelajaran sedang berlangsung, contohnya memainkan smartphone, bercanda dan mengobrol dengan teman sebangku, bahkan ada yang tidur. (3) Peserta didik kurang memahami materi pembelajaran Sosiologi. Hal ini disebabkan oleh kurang tertariknya peserta didik terhadap pembelajaran Sosiologi sehingga kurang memperhatikan ketika guru menjelaskan materi. Hal ini juga berlaku ketika peserta didik mempelajari istilah-istilah Sosiologi, seperti mobilitas, integrasi, stratifikasi, dll, peserta didik kesulitan untuk memahaminya. Sehingga berdampak pada hasil belajar peserta didik menjadi rendah.

\section{Tahap desain (design)}

Tahap desain terdiri dari 2, yaitu:

\section{Rancangan Produk}

1) Rencana Pelaksanaan Pembelajaran (RPP)

Rencana Pelaksanaan Pembelajaran disusun sesuai dengan hasil analisis kurikulum yang telah dilakukan oleh peneliti, yaitu sesuai dengan kurikulum 2013. Model pembelajaran yang digunakan dalam RPP yaitu model problem based learning, sehingga sintaks pembelajaran yang ada dalam RPP dapat disesuaikan dengan sintaks model problem based learning.

2) Lembar Kerja Peserta Didik (LKPD)

LKPD yang dibuat disesuaikan dengan model pembelajaran problem based learning. LKPD ini menyajikan gambaran masalah yang ada di sekitar lingkungan masyarakat sehingga dapat membantu peserta didik untuk memahami materi integrasi sosial. Dalam LKPD ini peserta didik juga dituntut untuk dapat menemukan solusi dari permasalahan yang ada sehingga keaktifan peserta didik dapat meningkat. 


\section{Rancangan Instrumen Penelitian}

1) Lembar Validasi

Lembar validasi ditujukan kepada validator yaitu dosen jurusan Sosiologi, Universitas Negeri Padang dan kepada guru Sosiologi yang mengajar di SMAN 1 Payakumbuh. Lembar ini memiliki tujuan untuk mengetahui tingkat kevalidan produk yang dikembangkan.

2) Lembar Praktikalitas

Lembar praktikalitas ditujukan kepada peserta didik yang berjumlah sebanyak 30 orang setelah dilakukan uji coba terhadap produk yang dikembangkan. Lembar ini bertujuan untuk mengukur kepraktisan dari produk yang telah diuji cobakan.

3) Soal pretest dan posttest

Soal pretest dan posttest ini berupa soal pilihan ganda sebanyak 25 butir soal yang ditujukan kepada peserta didik baik itu sebelum dilakukan uji coba produk maupun setelah dilakukan uji coba produk. Soal pretest dan posttest ini bertujuan untuk mengukur keefektifan produk yang telah diuji cobakan.

\section{Tahap pengembangan (development)}

Pada tahap pengembangan ini, produk yang telah selesai didesain kemudian dibuat dan dijadikan produk yang siap untuk dinilai dan diuji cobakan. Namun, sebelum diuji cobakan terlebih dahulu dilakukan penilaian kevalidan produk oleh ahli, yaitu Bapak Junaidi dan Bapak Erianjoni selaku dosen Sosiologi Universitas Negeri Padang. Selain itu validasi ini juga dilakukan oleh guru mata pelajaran Sosiologi yang mengajar di SMAN 1 Payakumbuh. Adapun hasil dari validasi produk tersebut adalah:

\section{Hasil Validasi Rencana Pelaksanaan Pembelajaran (RPP)}

\section{Tabel 2. Hasil Validasi RPP}

\begin{tabular}{|c|c|c|c|c|c|c|}
\hline \multirow[t]{2}{*}{ No } & \multirow[t]{2}{*}{ Aspek yang dinilai } & \multicolumn{3}{|c|}{ Validator } & \multirow[t]{2}{*}{ Rata-Rata Skor } & \multirow[t]{2}{*}{ Kategori } \\
\hline & & Ahli 1 & Ahli 2 & Guru & & \\
\hline 1. & Identitas RPP & 4 & 4 & 4 & 4 & Baik \\
\hline 2. & Perumusan Indikator & 5 & 4,5 & 4 & 4,4 & Sangat Baik \\
\hline 3. & $\begin{array}{ll}\text { Perumusan } & \text { Tujuan } \\
\text { Pembelajaran } & \end{array}$ & 5 & 4 & 4 & 4,3 & Sangat Baik \\
\hline 4. & $\begin{array}{ll}\text { Pemilihan } & \text { Materi } \\
\text { Pembelajaran } & \end{array}$ & 4,5 & 4,5 & 5 & 4,6 & Sangat Baik \\
\hline 5. & $\begin{array}{l}\text { Model/ Pendekatan } \\
\text { /Metode Pembelajaran }\end{array}$ & 4,5 & 4,5 & 4 & 4,3 & Sangat Baik \\
\hline 6. & Media Pembelajaran & 4 & 4 & 4,5 & 4,1 & Baik \\
\hline 7. & Sumber Belajar & 4 & 4 & 4 & 4 & Baik \\
\hline 8. & $\begin{array}{l}\text { Langkah-langkah } \\
\text { Pembelajaran }\end{array}$ & 4 & 4,5 & 4,7 & 4,3 & Sangat Baik \\
\hline 9. & Aspek Penilaian & 4 & 4 & 4,3 & 4,1 & Baik \\
\hline 10. & Penggunaan Bahasa & 4 & 4 & 4 & 4 & Sangat Baik \\
\hline & Jumlah & & & & 4,21 & Sangat Baik \\
\hline
\end{tabular}

Berdasarkan hasil validasi RPP oleh ahli dan guru, dapat dilihat bahwa dari aspek validasi terdiri dari 10 butir, yang mana 10 butir aspek ini merupakan aspek yang harus ada dalam penyusunan sebuah RPP. Dari 10 butir aspek validasi RPP, 6 aspek masuk dalam kategori sangat baik dan 4 aspek lainnya mendapat kategori baik. Sehingga dari 10 butir aspek validasi RPP mendapat skor rata-rata 4,21 dan masuk dalam kategori sangat baik. 
Hasil Validasi Lembar Kerja Peserta Didik (LKPD)

Tabel 3. Hasil Validasi LKPD

\begin{tabular}{|c|c|c|c|c|c|c|}
\hline \multirow[t]{2}{*}{ No } & \multirow[t]{2}{*}{ Aspek yang dinilai } & \multicolumn{3}{|c|}{ Validator } & \multirow{2}{*}{$\begin{array}{l}\text { Rata-Rata } \\
\text { Skor }\end{array}$} & \multirow[t]{2}{*}{ Kategori } \\
\hline & & Ahli 1 & Ahli 2 & Guru & & \\
\hline 1. & $\begin{array}{l}\text { Kelengkapan } \\
\text { LKPD }\end{array}$ & 4,7 & 4,5 & 4,2 & 4,4 & Sangat Baik \\
\hline 2. & Kesesuaian Isi dan Materi & 4,4 & 4,2 & 4,2 & 4,2 & Sangat Baik \\
\hline 3. & Kebahasaan & 4,3 & 4,3 & 4 & 4,2 & Sangat Baik \\
\hline 4. & $\begin{array}{l}\text { Kesesuaian Syarat Model } \\
\text { Problem Based Learning }\end{array}$ & 4 & 4,5 & 4,5 & 4,3 & Sangat Baik \\
\hline & Jumlah & & & & 4,2 & Sangat Baik \\
\hline
\end{tabular}

Berdasarkan hasil validasi LKPD (Lembar Kerja Peserta Didik) dapat dilihat bahwa dari 4 aspek yang terdapat dalam penilaian kevalidan LKPD, semuanya masuk ke dalam kategori sangat baik. Rata-rata skor keseluruhan dari penilaian LKPD menunjukkan angka 4,2 yang berarti masuk ke dalam kategori sangat baik.

\section{Tahap implementasi (implementation)}

Pada tahap ini produk yang telah selesai diuji kevalidannya dan telah dinyatakan valid kemudian diuji cobakan di sekolah yang bersangkutan, yaitu di SMAN 1 Payakumbuh. Produk diuji cobakan dalam pembelajaran Sosiologi dengan berbasis Pada tahap ini produk yang telah selesai diuji kevalidannya dan telah dinyatakan valid kemudian diuji cobakan di sekolah yang bersangkutan, yaitu di SMAN 1 Payakumbuh. Produk diuji cobakan dalam pembelajaran Sosiologi dengan berbasis model problem based learning sebanyak 4 kali pertemuan. Setelah produk diuji cobakan, peneliti juga memberikan format penelitian praktikalitas produk yang ditujukan kepada peserta didik. Penilaian praktikalitas ini bertujuan untuk mengetahui apakah produk yang diujicobakan dapat memberikan manfaat kepada peserta didik sebagai objek dari penelitian. Berikut ini adalah hasil dari tahap implementasi, yaitu:

\section{Hasil uji praktikalitas produk}

Tabel 4. Hasil Uji Praktikalitas Produk

\begin{tabular}{llccc}
\hline No & Aspek Yang Dinilai & Jumlah Item & Rata-rata & Keterangan \\
\hline 1. & Materi & 3 & 4,24 & Sangat Baik \\
\hline 2. & Penyajian & 3 & 4,35 & Sangat Baik \\
\hline 3. & Bahasa & 2 & 4,51 & Sangat Baik \\
\hline 4. & Ketertarikan & 3 & 4,10 & Baik \\
\hline & Jumlah & $\mathbf{1 1}$ & $\mathbf{4 , 2 8}$ & Sangat Baik \\
\hline
\end{tabular}

Berdasarkan hasil uji praktikalitas produk, terdapat 4 aspek yang dinilai. Aspek materi yang berjumlah 3 item mendapatkan rata-rata 4,24 dengan kategori sangat praktis. Aspek penyajian produk yang berjumlah 3 item mendapatkan rata-rata 4,35 dengan kategori sangat praktis. Aspek bahasa yang berjumlah 2 item mendapatkan rata-rata 4,51 dengan kategori sangat praktis. Aspek ketertarikan yang berjumlah 3 item mendapatkan rata-rata 4,10 dengan kategori praktis. Sehingga secara keseluruhan hasil dari uji praktikalitas produk mendapatkan rata-rata 4,28 dengan kategori sangat praktis. 


\section{Hasil uji efektifitas produk}

Tabel 5. Hasil Uji Efektivitas Produk

\begin{tabular}{|c|c|c|c|c|c|c|}
\hline No. & $\begin{array}{l}\text { Nama } \\
\text { Siswa }\end{array}$ & Pretest & Posttest & $\mathbf{D}$ & $(x) d=d-m d$ & $(x 2) d$ \\
\hline 1. & AA & 44 & 76 & 32 & 10,27 & 105,4729 \\
\hline 2. & $\mathrm{APK}$ & 76 & 80 & 4 & $-17,73$ & 314,3529 \\
\hline 3. & ANB & 64 & 80 & 16 & $-5,73$ & 32,8329 \\
\hline 4. & ATP & 76 & 80 & 4 & $-17,73$ & 314,3529 \\
\hline 5. & ADP & 72 & 84 & 12 & $-9,73$ & 94,6729 \\
\hline 6. & DDP & 56 & 88 & 32 & 10,27 & 105,4729 \\
\hline 7. & DJP & 40 & 76 & 36 & 14,27 & 203,6329 \\
\hline 8. & EW & 68 & 88 & 20 & $-1,73$ & 2,9929 \\
\hline 9. & GZ & 76 & 88 & 12 & $-9,73$ & 94,6729 \\
\hline 10. & HPP & 64 & 76 & 12 & $-9,73$ & 94,6729 \\
\hline 11. & $\mathrm{HHT}$ & 64 & 76 & 12 & $-9,73$ & 94,6729 \\
\hline 12. & IMB & 48 & 76 & 28 & 6,27 & 39,3129 \\
\hline 13. & $\mathrm{KO}$ & 20 & 76 & 56 & 34,27 & $1.174,4329$ \\
\hline 14. & MNF & 80 & 92 & 12 & $-9,73$ & 94,6729 \\
\hline 15. & MNA & 36 & 84 & 48 & 26,27 & 690,1129 \\
\hline 16. & MR & 72 & 80 & 8 & $-13,73$ & 188,5129 \\
\hline 17. & MG & 64 & 76 & 12 & $-9,73$ & 94,6729 \\
\hline 18. & MCS & 40 & 80 & 40 & 18,27 & 333,7929 \\
\hline 19. & $\mathrm{NZ}$ & 64 & 84 & 20 & $-1,73$ & 2,9929 \\
\hline 20. & NP & 64 & 72 & 8 & $-13,73$ & 188,5129 \\
\hline 21. & PPZ & 32 & 72 & 40 & 18,27 & 333,7929 \\
\hline 22. & $\mathrm{RP}$ & 72 & 76 & 4 & $-17,73$ & 314,3529 \\
\hline 23. & RMF & 56 & 80 & 24 & 2,27 & 5,1529 \\
\hline 24. & $\mathrm{RB}$ & 56 & 76 & 20 & $-1,73$ & 2,9929 \\
\hline 25. & $\mathrm{SH}$ & 60 & 88 & 28 & 6,27 & 39,3129 \\
\hline 26. & SNS & 64 & 76 & 12 & $-9,73$ & 94,6729 \\
\hline 27. & SNA & 40 & 80 & 40 & 18,27 & 333,7929 \\
\hline 28. & SRP & 56 & 80 & 24 & 2,27 & 5,1529 \\
\hline 29. & $\mathrm{ZA}$ & 64 & 84 & 20 & $-1,73$ & 2,9929 \\
\hline 30. & ZKI & 68 & 84 & 16 & $-5,73$ & 32,8329 \\
\hline & Jumlah & 1.756 & 2.408 & 652 & & $5.429,867$ \\
\hline
\end{tabular}

Berdasarkan hasil uji efektifitas produk menggunakan rumus T-test dapat dilihat bahwa skor $\mathrm{t}$ hitung adalah 8,72 dan t tabel dengan $\mathrm{df}=\mathrm{N}-1$ atau $30-1=29$ dengan $\alpha=0,05$ maka $\mathrm{t}$ tabel adalah 2,045 sehingga $t$ hitung $>\mathrm{t}$ tabel. Artinya hasil tersebut adalah terdapat perbedaan yang signifikan antara hasil pretest dengan hasil posttest peserta didik. Sehingga dapat peneliti simpulkan bahwa produk yang dikembangkan efektik untuk meningkatkan hasil belajar siswa pada mata pelajaran Sosiologi.

\section{Tahap evaluasi (evaluation)}

Tahap terakhir dari proses pengembangan ini adalah tahap evaluasi. Pada tahap evaluasi ini produk yang telah selesai diimplementasikan kemudian dilakukan evaluasia untuk membuat produk menjadi lebih baik lagi. Evaluasi dilakukan dengan saran-saran dan komentar yang 
sudah diberikan oleh ahli, guru, serta juga peserta didik. Berikut ini adalah hasil dari tahap evaluasi:

\section{Revisi I}

Revisi I dilakukan setelah produk diuji kevalidannya oleh ahli (dosen) dan guru. Sebelum produk diuji cobakan, terlebih dahulu dilakukan uji kevalidan oleh ahli dan guru. Komentar dan saran yang diberikan oleh validator kemudian dijadikan sebagai acuan dalam tahap revisi I. Berikut ini adalah tabel revisi I produk:

Tabel 6. Revisi Produk

\begin{tabular}{|c|c|c|c|}
\hline No & Komentar dan Saran & Sebelum Revisi & Sesudah Revisi \\
\hline 1. & $\begin{array}{l}\text { Sebaiknya soal yang } \\
\text { dibuat berangkat dari } \\
\text { kasus untuk menentukan } \\
\text { konsep }\end{array}$ & $\begin{array}{l}\text { Soal yang dibuat bukan } \\
\text { berangkat dari kasus yang } \\
\text { dibahas, namun lebih } \\
\text { kepada teks buku. }\end{array}$ & $\begin{array}{l}\text { Soal yang dibuat berangkat } \\
\text { dari kasus yang sedang } \\
\text { dibahas. }\end{array}$ \\
\hline 2. & $\begin{array}{l}\text { Kaitkan secara langsung } \\
\text { soal dengan kasus atau } \\
\text { gambar }\end{array}$ & $\begin{array}{l}\text { Soal yang dibuat belum } \\
\text { dikaitkan dengan kasus } \\
\text { atau gambar }\end{array}$ & $\begin{array}{l}\text { Soal yang dibuat dikaitkan } \\
\text { dengan kasus dan gambar }\end{array}$ \\
\hline 3. & $\begin{array}{l}\text { Terdapat soal yang } \\
\text { kurang berkaitan dengan } \\
\text { materi }\end{array}$ & $\begin{array}{l}\text { Soal yang dibuat kurang } \\
\text { berkaitan dengan materi } \\
\text { (sedikit menyimpang) }\end{array}$ & $\begin{array}{l}\text { Soal yang dibuat sudah } \\
\text { berkaitan dengan materi. }\end{array}$ \\
\hline
\end{tabular}

\section{Revisi II}

Revisi II dilakukan setelah produk diuji kevalidannya oleh validator kemudian diuji cobakan di sekolah yang bersangkutan. Setelah produk diuji cobakan, peserta didik kemudian diminta untuk mengisi angket praktikalitas dan menyampaikan komentar dan saran-saran mengenai produk yang telah diuji cobakan. Komentar dan saran dari peserta didik tersebut kemudian akan dijadikan acuan dalam proses revisi II.

\section{Pembahasan}

Penelitian ini berjudul "Pengembangan Perangkat Pembelajaran Berbasis Model Problem Based Learning Untuk Meningkatkan Hasil Belajar Siswa Pada Pembelajaran Sosiologi Kelas XI IPS di SMAN 1 Payakumbuh". Penelitian ini dilakukan di kelas XI IPS 1 SMAN 1 Payakumbuh dengan jumlah peserta didik sebanyak 30 orang. Pembahasan ini akan dilakukan sesuai dengan 3 tujuan penelitian, yaitu : 1) Mengetahui kelayakan/kevalidan perangkat pembelajaran yang dikembangkan dengan berbasis model problem based learning, 2) Mengetahui kepraktisan perangkat pembelajaran yang dikembangkan dengan berbasis model problem based learning, 3) Mengetahui keefektifan perangkat pembelajaran yang dikembangkan dengan berbasis model problem based learning.

Penelitian ini dilakukan secara online (daring) dikarenakan penelitian secara langsung/tatap muka tidak memungkinkan untuk dilakukan disebabkan oleh pandemi covid-19 yang sedang mewabah. Sesuai dengan peraturan pemerintah, pembelajaran dilakukan secara daring (dalam jaringan) dari rumah masing-masing atau disebut SFH (school from home). Pembelajaran daring dilakukan dengan menggunakan aplikasi chat whatsapp dan aplikasi zoom. Peneliti dan peserta didik membentuk grup kelas di aplikasi chat whatsapp kemudian 
berkomunikasi dengan peserta didik melalui grup tersebut. Pembelajaran daring dilakukan dalam 4 kali pertemuan selama 2 minggu. Pada pertemuan pertama, peneliti dan peserta didik melakukan perkenalan dan peneliti memberikan soal pretest kepada peserta didik. Pada pertemuan kedua, peneliti dan peserta didik melakukan pembelajaran daring dengan materi pengertian integrasi sosial,

Setelah pembelajaran daring dilakukan, kemudian peneliti melakukan olah data terhadap data-data yang telah didapatkan untuk mengetahui kevalidan, kepraktisan, dan keefektifan produk. Berdasarkan data validitas RPP yang didapatkan, yang diisi oleh validator dosen sebanyak 2 orang, dan guru Sosiologi 1 orang, didapatkan hasil rata-rata dari 10 aspek yang dinilai yaitu 4,21 yang artinya berada pada kategori sangat baik. Berdasarkan data validitas LKPD yang didapatkan, yang diisi oleh validator dosen sebanyak 2 orang dan guru Sosiologi sebanyak 1 orang, didapatkan hasil rata-rata dari 4 aspek yang dinilai yaitu 4,20 yang artinya berada pada kategori sangat baik.

Berdasarkan data praktikalitas yang didapatkan, dimana data praktikalitas ini diisi oleh peserta didik sebanyak 30 orang didapatkan hasil rata-rata dari 4 aspek yang dinilai yaitu 4,28 yang artinya berada pada kategori sangat baik. Sementara itu, berdasarkan data hasil uji efektifitas yang didapatkan, dimana data hasil uji efektifitas ini didapatkan dari hasil pretest dan posttest peserta didik yang berjumlah sebanyak 30 orang. Data hasil uji efektifitas ini diolah menggunakan rumus $\mathrm{T}$-test yang menunjukkan hasil yaitu $\mathrm{t}$ hitung sebanyak 8,72 dan $\mathrm{t}$ tabel dengan $\mathrm{df}=\mathrm{N}-1$ atau $30-1=29$ dengan $\alpha=0,05$ maka t tabel adalah 2,045 sehingga $t$ hitung $>\mathrm{t}$ tabel. Arti dari hasil tersebut adalah terdapat perbedaan yang signifikan antara hasil pretest dengan hasil posttest peserta didik. Sehingga dapat peneliti simpulkan bahwa produk yang dikembangkan efektif untuk meningkatkan hasil belajar siswa pada mata pelajaran Sosiologi.

\section{Kesimpulan}

Perangkat pembelajaran yang dikembangkan dinyatakan valid, praktis, dan efektif untuk digunakan dalam pembelajaran Sosiologi kelas XI pada materi integrasi sosial. Berdasarkan hasil uji validitas RPP menunjukkan bahwa secara keseluruhan mendapatkan rata-rata 4,21 yang artinya masuk dalam kategori sangat baik, sedangkan hasil uji validitas LKPD menunjukkan bahwa secara keseluruhan mendapatkan rata-rata 4,20 yang artinya masuk dalam kategori sangat baik. Berdasarkan hasil uji praktikalitas menunjukkan bahwa secara keseluruhan mendapatkan rata-rata 4,28 yang artinya masuk dalam kategori sangat praktis. Berdasarkan hasil uji efektifitas menunjukkan bahwa hasil thitung adalah 8,72 dan $\mathrm{t}$ tabel dengan $\mathrm{df}=\mathrm{N}-1$ atau $30-1=29$ dengan $\alpha=0,05$ maka $t$ tabel adalah 2,045 sehingga $t$ hitung $>t$ tabel. Arti dari hasil tersebut adalah terdapat perbedaan yang signifikan antara hasil pretest dengan hasil posttest peserta didik. Sehingga dapat peneliti simpulkan bahwa produk yang dikembangkan efektif untuk meningkatkan hasil belajar peserta siswa pada mata pelajaran Sosiologi.

\section{Daftar Pustaka}

Al-Thabany, \& Badar, T. I. (2015). Mendesain Model Pembelajaran Inovatif, Progresif, Kontekstual: Konsep, Landasan, dan Implementasinya Pada Kurikulum 2013 (Kurikulum Tematik Integratif I TIK). Jakarta: Prenadamedia Group.

Argusni, R., \& Sylvia, I. (2018). Pelaksanaan Model Problem Based Learning untuk Meningkatkan Kemampuan Problem Solving Siswa Kelas XI IIS SMAN 16 Padang. 1(1), 52-59. https://doi.org/https://doi.org/10.24036/sikola.v1i1.9

Fariroh, A., \& Anggraito, Y. U. (2015). Pengembangan Perangkat Pembelajaran Berbasis Problem Based Learning Pada Materi Virus Kelas X SMA. Journal of Biology Education, 5(2), 192-197. 
Jasmin, R. N. (2018). Pengembangan Perangkat Pembelajaran Berorientasi Pada Scientific Approach Berbasis Mobile Learning Guna Meningkatkan Minat Belajar dan Hasil Belajar Fisika Peserta Didik Kelas XI. Jurnal Fakultas Matematika dan Ilmu Pengetahuan Alam, 1(1), 75. https://doi.org/10.29333/aje.2019.423a

Mukminan, M. (2013). Kurikulum 2013 pada Jenjang Pendidikan Dasar dan Menengah. Makalah disajikan padaWorkshop Pengkajian Kurikulum Pendidikan Dasar dan Menengah. LPPM Universitas Negeri Yogyakarta.

Sugiyono, S. (2009). Metode Penelitian Kuantitatif, Kualitatif, dan R\&D. Bandung: Alfabeta.

Sumantri, M. S. (2016). Strategi Pembelajaran: Teori dan Praktik di Tingkat Pendidikan Dasar. Jakarta: Rajawali Pers.

Sylvia, I., Anwar, S., \& Khairani, K. (2019). Pengembangan Instrumen Penilaian Autentik Berbasis Pendekatan Authentic Inquiry Learning Pada Mata Pelajaran Sosiologi di Sekolah Menengah Atas. Socius, 6(2), 103. https://doi.org/10.24036/scs.v6i2.162

Undang-Undang No. 20 Tahun 2003 Bab 1 Pasal 1 Ayat 1 tentang Sistem Pendidikan Nasional. 